\title{
Development and Analysis of a Spiral Theory-based
}

Cybersecurity Curriculum

Project Team: Godmar Back, Vinod Lohani, Calvin Ribbens, Paul Plassmann, Kira

Gantt, Dwight Barnette, David McPherson, Debarati Basu, William Naciri

Goal: Enhance cybersecurity learning experiences of students at Virginia Tech's large engineering program

\section{Objectives:}

- Development and implementation of a unique curriculum delivery model in cybersecurity into Computer Science and Computer Engineering curricula using Jerome Bruner's spiral curriculum theory Engineering education research to evaluate students' learning experiences

\section{Scientific Impact:}

Research findings regarding how students learn and get motivated about cybersecurity concepts

Curriculum development/ implementation experiences to infuse cybersecurity into a large engineering program

\begin{tabular}{|c|c|c|c|}
\hline $\begin{array}{l}\text { Level } 4 \\
\text { System and Network Level } \\
\text { Threats and Defences } \\
\text { Proiect: "Secure Server" }\end{array}$ & \rangle & $\begin{array}{c}\text { CS } 3214 \\
\text { Computer Systems }\end{array}$ & $\begin{array}{c}\text { ECE } 3574 \\
\text { Applied Software } \\
\text { Design }\end{array}$ \\
\hline & & & \\
\hline $\begin{array}{l}\text { Level } 3 \\
\text { Memory Threats and } \\
\text { Vulnerabilities }\end{array}$ & & $\begin{array}{c}\text { CS } 2506 \\
\text { Computer Org. }\end{array}$ & $\begin{array}{c}\text { ECE } 2500 \\
\text { Computer Org. }\end{array}$ \\
\hline Project: "Heap Spraying attack" & & & \\
\hline $\begin{array}{l}\text { Level } 2 \\
\text { Threats to Resources } \\
\text { Project: "Resource Leaks" }\end{array}$ & & $\begin{array}{c}\text { CS } 2114 \\
\text { Software Design \& } \\
\text { Data Structures }\end{array}$ & $\begin{array}{c}\text { ECE } 2574 \\
\text { Data Structures \& } \\
\text { Algorithms }\end{array}$ \\
\hline $\begin{array}{l}\text { Level } 1 \\
\text { Threats to Software } \\
\text { Project: "Data Integrity and } \\
\text { authenticity" }\end{array}$ & & $\begin{array}{c}\text { CS } 1114 \\
\text { Introduction to } \\
\text { Software Design }\end{array}$ & $\begin{array}{c}\text { ECE } 1574 \\
\text { Engineering Problem } \\
\text { Solving with C++ }\end{array}$ \\
\hline $\begin{array}{l}\text { Spiraling Theme: } \\
\text { Handling threats to software } \\
\text { for securing personal } \\
\text { information }\end{array}$ & $\begin{array}{c}\text { Course } \\
\text { Integration } \\
\text { Each lev }\end{array}$ & $\begin{array}{l}\text { Computer } \\
\text { Science }\end{array}$ & $\begin{array}{c}\text { Electrical \& } \\
\text { Computer Engineering } \\
\text { lours class time per course }\end{array}$ \\
\hline
\end{tabular}

\section{Development and pilot implementation of} learning level-1 (L1) completed during Fall 2016 Learning Objective of L1 :

L01: Define cybersecurity principles: integrity and authenticity LO2: Define and explain an adversary model

LO3: Describe potential security threats from non-validated input

LO4: Explain the purpose of ensuring the integrity and authenticity of data in real-world scenario LO5: Apply the process of ensuring data integrity and authenticity through authentic problem solving

\section{Implementation in CS1114 with 423 students}

\section{Lecture topics:}

- The Cyber security CIA/AAA goals (Confidentiality, Integrity, Availability / Authenticity, Anonymity, Assurance) was stressed

- The Adversary/Threat model assumptions and attack vectors was covered

- The Diffie-Hellman public-key cryptography algorithm was explained and demonstrated to students

- Concept of Digital Signatures was introduced

- One-way hashing, as used in digital signing, and its differences from encryption was presented

- The processes of Digital Signature generation and verification was covered

Authentic Activity:

Students coded a Java program to perform verification upon records in file that were Digitally Signed generating a report

\begin{tabular}{|llll|}
\hline $\begin{array}{l}\text { Students' Perceptions on } \\
\text { Motivational Constructs }\end{array}$ & $\begin{array}{l}\text { Strongly } \\
\text { Agree (\%) }\end{array}$ & $\begin{array}{l}\text { Agree } \\
(\%)\end{array}$ & $\begin{array}{l}\text { Somewhat } \\
\text { agree (\%) }\end{array}$ \\
\hline $\begin{array}{l}\text { the cybersecurity initiative was useful to } \\
\text { his/her future }\end{array}$ & 20.10 & 39.03 & 25.10 \\
\hline $\begin{array}{l}\text { the instructional method and } \\
\begin{array}{l}\text { cybersecurity initiative were interesting or } \\
\text { enjoyable }\end{array}\end{array}$ & 15.39 & 36.45 & 26.00 \\
\hline
\end{tabular}

\section{Research Questions:}

1. How effective are the spiral theory-based learning levels in enhancing students' core- knowledge and skills in

cybersecurity?

2. How does students' motivation vary across gender, ethnic backgrounds, academic levels, and disciplines when participating in the cybersecurity learning levels?

\section{Broader Impact:}

-Enhance recruitment of informed undergraduates into the CyberCorps and VT-Scholarship for Service program at VT - Increase the number of graduates who accept employment in the cybersecurity field or pursue graduate studies in cybersecurity

- Develop an education theory based curriculum model for cybersecurity

\section{Post-Survey Results (n=199 out of $600+$ students)}

Computer Science: 25\%; Computer Eng.: 11.22\%; General Eng.: 18.37\%; Other Disciplines: $45.41 \%$

\section{Students' answers to} content questions

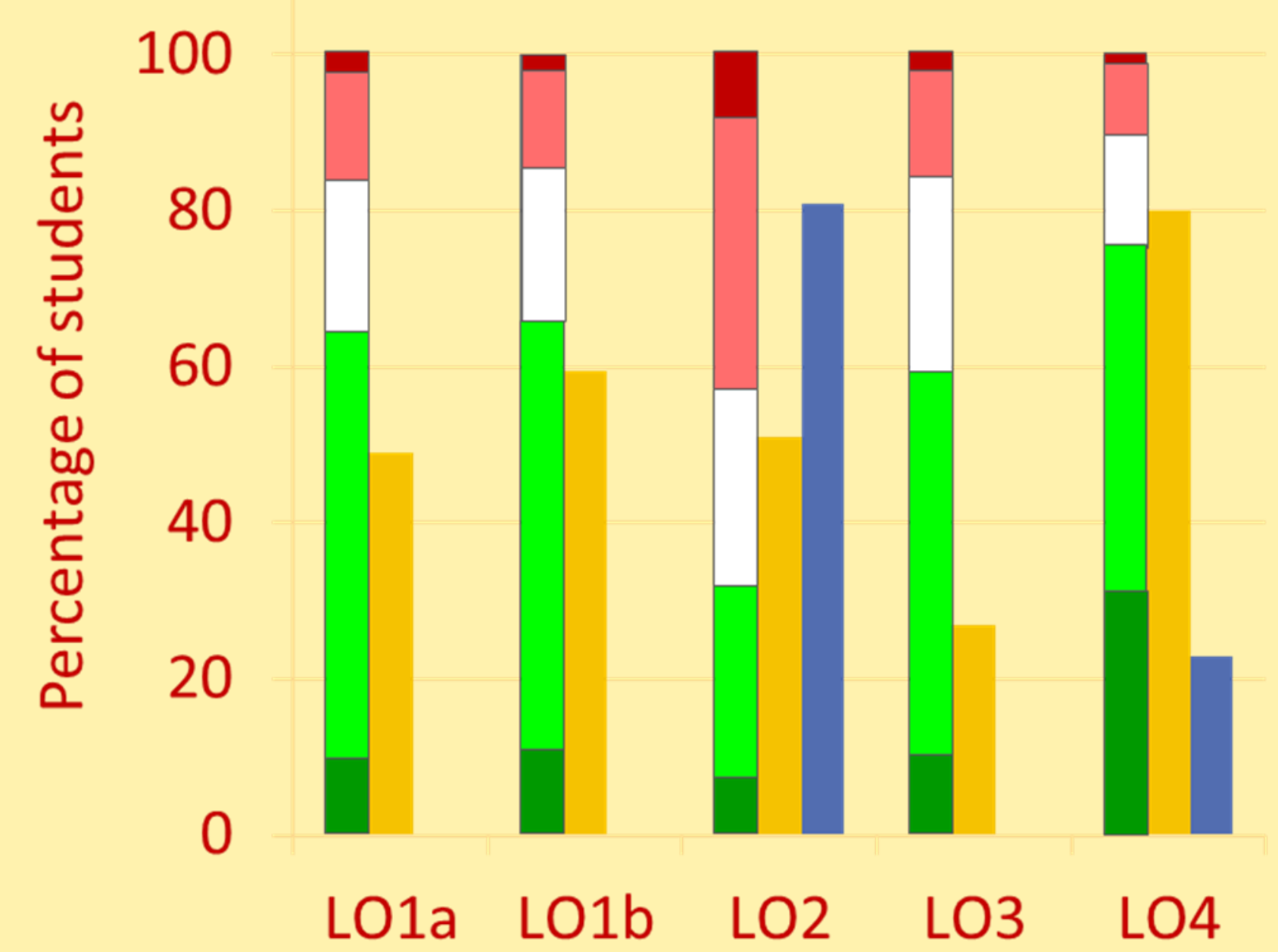

Content Question 1

Content Question 2

Students' perception on LOS

Strongly disagree

Disagree

Neither agree nor

disagree

Agree

Strongly Agree

Interested in meeting the PIs? Attach post-it note below! 